This document has been downloaded from

TamPub - The Institutional Repository of University of Tampere

\title{
Post-print
}

The permanent address of the publication is

http://urn.fi/URN:NBN:fi:uta-201510132359

Author(s):

Title:

Year:

Journal Title:

Vol and number:

Pages:

ISSN:

Discipline:

School /Other Unit:

Item Type:

Language:

DOI:

URN:

Subject:
Otonkorpi-Lehtoranta, Katri; Leinonen, Minna; Nikkanen, Risto; Heiskanen, Tuula

Intersections of gender, age and occupational group in the Finnish defence forces

2015

Equality, Diversity and Inclusion: An International Journal $34: 7$

593-607

2040-7149

Sociology; Other social sciences

School of Social Sciences and Humanities

Journal Article

en

http://dx.doi.org/10.1108/EDI-03-2015-0016

URN:NBN:fi:uta-201510132359

gender; age; occupational group; intersectionality;

military; the Finnish defence forces

All material supplied via TamPub is protected by copyright and other intellectual property rights, and duplication or sale of all part of any of the repository collections is not permitted, except that material may be duplicated by you for your research use or educational purposes in electronic or print form. You must obtain permission for any other use. Electronic or print copies may not be offered, whether for sale or otherwise to anyone who is not an authorized user. 


\section{Intersections of gender, age and occupational group in the Finnish Defence Forces}

\section{Introduction}

An intensive scientific and political debate around equality issues is currently underway in both Europe and the USA. In scientific discussions, the challenges are mainly framed with the concepts of intersectionality or diversity. Especially in gender studies, intersectionality has become a major paradigm and a prevalent concept in understanding multiple differences (e.g. Crenshaw 1991; Lykke 2005; McCall 2005; de los Reyes \& Mulinari 2005). In this article, we apply intersectional analysis to the organizational structure and practices of the Finnish Defence Forces (FDF) during times of change.

The concept of intersectionality has been used to refer to complex relations between social categories, such as gender, ethnicity, race, class, sexuality, age/generation, nationality etc., and to explain how they create inclusionary and exclusionary boundaries and hierarchies of differential access to resources (Lykke 2005; 2010; Yuval-Davis 2006, 199). The wide publicity of the topic has brought new researchers to the field, made visible gaps in knowledge that concern theoretical and methodological issues (Acker 2006a; 2006b, 2012; McCall 2005; Yuval-Davis 2006), and highlighted the implications of framing the issue for policy (Thorvaldsdottir 2007; Verloo 2006; 2013).

Aiming to change inequalities in organizations requires the identification of the factors that lead to less oppressive organizational environments (cf. Holvino 2010, 264). However, before change strategies can be applied, inequality processes must be made visible. We have encountered this problem in contexts where organizations are compiling their legally mandated equality plans (e.g. Heiskanen, Otonkorpi-Lehtoranta, Leinonen \& Ylöstalo 2015). Both the intersections of social categories and the organizational context must be taken into account. To initiate change in organizations, Britton and Logan (2008, 116, 118-119) as well as Acker (2006a, 2006b) call for more research on the mechanisms through which inequalities are reproduced. In this article, we focus on the challenges of multiple differences arising from organizational-level structures and mechanisms and link the examination to the discussion of intersectional methodology. Leslie McCall (2005) was one of the first researchers to highlight the methodological issues and problems introduced by the complexity of intersectionality, and her work has inspired many other researchers to develop the methodology of practicing intersectionality in empirical research (e.g. Choo \& Ferree 2010, Spierings 2012).

Also inspired by McCall's ideas, we agree that researchers should focus on the dynamic relationships between categories in addition to single analytical categories. In doing so, we seek to understand how privileges and disadvantages (Lykke 2010, 51; Tatli \& Özbilgin 2012) are distributed in organizations. Looking at interaction effects reveals whether people in different intersectional positions "are affected differently by similar processes” (Spierings 2012, 340) and highlights the possibilities and limitations of organization-level datasets.

The categories used in intersectional analyses (see e.g. Acker 2006, 2012; Holvino 2010) seem to be hierarchically ordered so that gender, race and class are usually central in research, and the lack of certain categories in analysis leads to doubts about the validity of the intersectionality conception used. Following Tatli \& Özbilgin (2011, 180), we call for a sense of contextuality in selecting the categories for study. In addition, strategic choices in the inclusion of the categories can be made in the analysis (Acker 2012, 220; Davis 2008, Holvino 2010, 261; Winker \& Degele 2011, 53) to 
locate power differences. We argue that the possibilities and limitations of organization-level datasets affect these choices.

In this article, we first explore how the interactions between categories of gender, age and position in the organization explain the concerns of employees in the changing military organization. Second, we investigate the kinds of intersectional mechanisms behind the empirical observations. Third, we contribute to the methodological debate on intersectionality, especially from the point of view of quantitative methods. In particular, we participate in filling the gap in the quantitative analysis of intersectional studies (e.g. Spierings 2012, 337) in the organizational context.

\section{A changing military organization as the context}

The Finnish Defence Forces form the organizational context of our study. This military organization consists of various kinds of social divisions that are mutually intertwined in many complex ways and are defined both in the formal structures of the organization and in its everyday practices. These include dynamic relationships between gender, age, and (horizontal and vertical) position, and earlier research indicates that these relationships are important in the (re)production of inequalities in military organizations (Heiskanen et al. 2015; Leinonen et al. 2008; Leinonen et al. 2012; Persson 2011; Tallberg 2009).

The FDF is a strongly male-dominated organization in which segregation according to gender and civil or military position is strong. Women are mainly represented in the civilian groups. The organization is undergoing structural changes, and there has been a decline in the number of civilian jobs. At the time of data collection, the organization was adjusting to cutbacks due to a governmental productivity programme, which included reorganizing some activities and forming service centres, especially for civilian-dominated work. This process was ongoing during our research, and all of the coming changes and demands for change were not yet known to the respondents. Military work has also seen some changes; the training of warrant officers was terminated with the aim of increasing the number of non-commissioned officers. The civil-military divide is enforced in the organizational structure. For example, civil and military personnel have different pay systems, and upwardly mobile career paths are preserved for officers. For officers, age is related to successive promotions and early retirement, whereas for civilians, ageing does not offer this kind of positive outlook to future career paths. There are at least two contradictory developments underway at the moment: the FDF and national defence is polarising into a core of military work with a margin of civil work, but at the same time, the military organization is reaching out to civil society using various kinds of networks (Tallberg 2009; 2010).

\section{Theoretical background}

During the last twenty-five years, intersectionality has become a widely utilized theoretical concept in understanding multiple differences and inequality in the social sciences, and especially in gender studies (Lykke 2010). Although a heavily debated concept (Lykke 2010, Davis 2008), intersectionality helps researchers to appreciate the complexity of their research field (Davis 2008, 79) and supports "an analytic sensibility" in understanding the constant interplay of social categories and power (Cho, Crenshaw \& McCall 2013, 795).

From a methodological and empirical research point of view, applying the concept has brought out new methodological challenges and the need to develop special tools to meet them. (McCall 2005, 1771-1772; Choo \& Ferree 2010) This article applies quantitative methods that are, all in all, scarcely used in feminist research (Spierings 2012, 332). McCall (2005) has made an influential 
contribution to broadening the methodological repertoire of intersectional studies by including quantitative analysis in addition to qualitative methods. McCall (2005, 1775-1794) utilizes an approach that she has named the intercategorical or categorical approach, the focus of which is on the unequal relationships of the existing social groups in a particular context. Categories, such as gender and race, act as anchors in the analysis. Since they are intertwined with other categories, the meanings and effects related to the categories can change. The analysis focuses on the nature of the relationships between the categories and any changes that occur in them; hence the main interest is in the complexity of the inequalities in existing relationships among various social groups. The approach therefore compares different social groups within and across analytical categories. McCall describes this process as the cross-classifying of categories. For example, in the case of exploring the relationship between gender and personnel group, gender must be cross-classified with the personnel group, and as there are three personnel groups (civilian workers, officers and other soldiers), this cross-classification produces six groups. Analysis proceeds by comparing one or two group relationships to a synthesis that brings the various parts of the analysis together, leading to a more detailed picture of the relationship of the different social groups.

In the field of intersectional feminist studies, mechanisms that produce inequalities are central to understanding why inequalities persist (Healy 2009, 88; Lykke 2010, 50-51). Mechanisms are context-dependent, which means that entities interacting to cause the events we observe must be studied in their specific context or environment. For example, in the context of working life, Acker (2006a, 442) proposes that the mechanisms producing inequalities should be examined in their specific organizational contexts. Changes in the forms of organization and employment give rise to new empirical questions regarding how inequalities and intersectionality are played out in organizations (Acker 2012, 221-222). To understand the complexity of certain social phenomena, it is necessary to specify under what conditions - in other words under what contextual factors - the certain observed correlations exist. Accomplishing a successful analysis therefore involves both the description of occurrences and the processes to which these occurrences are connected.

Joan Acker (2006a; 2006b) has approached the issue of intersectionality with the concept of inequality regimes, which brings together multiple determinants of inequality experiences. She claims that while the bases for inequality in organizations vary, all organizations have inequality regimes, which she defines as 'loosely interrelated practices, processes, actions and meanings that result in and maintain class, gender and racial inequalities within particular organizations' (2006a, 443). Inequality regimes tend to be fluid and changing, and they are linked to the inequality of the surrounding society. As examples of practices and processes that may contribute to the formation of inequality regimes, she mentions organizing general requirements of work and class hierarchies inside work organizations, recruitment and hiring, wage setting and supervisory practices, and informal interactions while working.

Quantitative methods are used here to increase our knowledge of the differences in the organizational positions of different groups of people (cf. Spierings 2012, 337). Situations of organizational change brings about worries and concerns for various social groups, which in turn tells us something about the positions of the groups. The following analysis focuses on the concerns expressed by the members of the FDF and the configurations of the positions in relation to the process of change. As indicated before, the FDF is structured in a way that differentiates groups from each other. We took these differentiations as the starting point for our analysis (cf. McCall 2005). A quantitative research design enables us to examine the degree to which differences and inequality exist empirically in the organization (cf. Spierings 2012, 343) and to trace structural relationships and their complexity across analytical categories (McCall 2005, 1786). In 
interpretations of empirical configurations, we refer to the prevailing practices that might function as the causal mechanisms of inequality regimes (cf. Healy 2009).

\section{Data and method}

The quantitative analysis is based on a survey addressed to every member of the FDF's salaried personnel in 2011. A total of 8,093 respondents returned the questionnaire, this meant a response rate of $54 \%$. The proportion of female to male respondents was $23 \%$ to $77 \%$. Most of the female respondents were civilians (88\%), whereas most of the male respondents were soldiers $(77 \%)$. The category of civilians includes blue-collar workers, office workers and experts. The data represents the proportions of occupational and gender groups well. For example, the proportion of civilians in FDF in 2011 was $41.9 \%$ and their proportion of all respondents $38.2 \%$ and for soldiers the same proportions were $58.1 \%$ and $61.8 \%$. A more detailed examination of the proportions shows that the difference between the proportion of personnel and proportion of all respondents was the highest among male officers (the first being $18.2 \%$ and the latter $21.8 \%$ ) and the smallest among female officers (the first being $0.5 \%$ and the latter $0.7 \%$ ).

Despite the large dataset, these proportions set some limitations for this research. This is due to strong gender segregation in the FDF. This especially concerns interactions between categories: it was not possible to include more than two-way interactions between the categories; otherwise, the number of respondents in some groups would have been too small for quantitative analysis.

Since the study uses statistical analysis, some statistical terminology is used. 'Dependent variable' refers to the outcome variable, and 'independent variable' refers to those variables that are used to predict or explain the values of the dependent variable. 'Main effect' refers to the extent to which the independent variable contributes to the value of the dependent variable, and 'interaction effect' refers to the situation where the main effect cannot be examined separately; the effects of some other factors have to be examined simultaneously in order to determine whether they perhaps strengthen or reduce the main effect. Statistical significance tests are used to ascertain the likelihood of the studied relationship between the variables being coincidental. Because the dependent variables in this research are binary, logistic regression was used in the statistical analysis. Logistic regression can be seen as a tool for analysing the complexity of relationships in a specific environment, and its purpose is to reveal certain mechanisms and patterns in the environment under investigation (Hurrell 2014; Olsen \& Morgan 2005). In logistic regression, it is possible to use both continuous and category explanatory variables, and thus it is quite free of limitations as a statistical multivariate analysis technique (Tabachnick \& Fidell 2013). Furthermore, it is also possible to use interaction terms between independent category variables to discover the complex relations between the explanatory variables and their categories. In this research, the statistical analyses were carried out using the SPSS Statistics program.

\section{Variables and stages of analyses}

In this article, the dependent variables are the concerns of the respondents: 'concerns over one's job continuity', 'concerns over one's well-being at work', 'concerns over changes in organizing one's work', 'concerns over the adequacy of one's skills', and 'concerns over changes in salaries'. All of these dependent variables are binary. In this research, it is crucial that the most important independent variables and their interaction effects are investigated in detail. The independent variables were chosen in successive stages, so some of them were dropped in the first and second stages of analysis. The final stage of analysis included three dependent variables: 'concerns over 
one's job continuity', 'concerns over one's well-being at work' and 'concerns over changes in organizing one's work'. Thus, two dependent variables were dropped from the final analysis.

Firstly, all the main effects of the independent variables that were concerned with the respondent's background information were examined. These variables were gender, age, personnel group, nature of work (staff, training or supporting task) and defence branch (defence command, air forces, armed forces, or naval forces). Secondly, the interaction terms were added. Two-way interactions between gender, age, personnel group, and defence branch were added to the logistic regressions. The independent variable nature of work was used in the regression without interactions because it was a complementary variable to the personnel group.

Finally, the dependent and independent variables were chosen. In the final analysis, there were three dependent variables and two different kinds of the independent variables. The process described concerned the respondent's background information. As a result, gender, age, and personnel group were chosen for the final analyses. In addition, four contextualizing independent variables were included in the analysis. Two of these variables were the respondent's 'opportunities to develop oneself at work' and 'opportunities to advance one's career'. Further, research on organizational change brought forth the need to examine social climate and the experiences of the management and leadership more closely. To be able to manage change processes successfully, employees' concerns need to be addressed properly by the management (Allen et al. 2007, 205-207). Thus, it is imperative to find out what those concerns are. Since organizational changes engender ambivalence among organization members, it is important to investigate what motivates both negative and positive responses (Piderit 2000, 792). Research also suggests that interpersonal relationships between peers and between supervisors and subordinates affect the way change is met. Peer perception of the organization heavily influences one's own perceptions. Therefore, these issues should be taken into account in processes of change. (Tierney 1999, 129-131) Consequently, two continuous sum variables were chosen in the analysis: one concerning the social climate and team spirit, and the other one concerning leadership and management in the respondent's work unit. Even though the primary focus of the analysis is on the relationships between gender, age, and personnel group, the main effects of these additional independent variables are also reported.

\section{Results}

In the first stage of analysis, all the independent variables (gender, age, personnel group, defence branch, and nature of work) had significant main effects on at least three of the five dependent variables. However, examining only the main effects is not sufficient in this research.

When interactions were added in the second stage, several significant interaction effects were found in the analysis between gender, age, and personnel group. Defence branch had no significant interactions, except for an interaction effect in 'concern over one's well-being at work', in which there was a significant interaction between age and defence branch. The older respondents reported lower well-being at work compared with younger respondents in some, but not in all, branches. Three statistically significant interactions were found in explaining 'concerns over one's job continuity' and two significant interactions were found in explaining 'concerns over one's well-being at work'. The dependent variables 'concerns over changes in organizing one's work' and 'concerns over changes in salaries' both had one significant interaction.

The most noteworthy result in the second stage of analysis was that the significant main effects of gender disappeared except when the dependent variable was 'concerns over the adequacy of one's skills'. This variable was also the only dependent variable with no significant interaction effects 
between explanatory variables. The disappearance of the main effects of gender refers to the interaction effects between gender and other independent variables (Hair et al. 2010). The independent variable nature of work was significant only in explaining the variable 'concerns over one's job continuity'. Those who were working in supporting tasks were the most worried about their job continuity.

Because no significant interaction effects were found in explaining 'concerns over the adequacy of one's skills', it was dropped from the final analysis as a dependent variable. The dependent variable 'concerns over changes in salaries' was also dropped and 'concerns over changes in one's work organization' was chosen because the organizational change in the FDF was about to start at the time when survey was carried out. Hence, the final analysis included three dependent variables.

In the final stage of analysis, there were significant main effects only for age and personnel group (Table 1). Age had significant main effects on all the three dependent variables. Younger respondents had more concerns over the continuity of their work than older respondents, but they had fewer worries about their well-being at work. Age also had a significant main effect on 'concerns over changes in organizing one's work' but there were no significant results in a comparison of the age categories. Of the different personnel groups, the civilians had more worries about their continuity of work than the officers and other soldiers. Finally, officers and civilian workers had fewer concerns over their well-being at work than other soldiers. The main effects among the different categories can be seen in the Odds Ratio (OR) column of Table 1. In the groups that had more concerns relative to reference category, the OR is greater than 1.0, and in those groups who had fewer concerns relative to reference category, the OR is less than 1.0.

Table 1. Results of the final logistic regressions. The significant $p$-values are in bold $(p \leq 0.05)$.

\begin{tabular}{|c|c|c|c|c|c|c|}
\hline \multirow[b]{3}{*}{ Independent variable } & \multicolumn{6}{|c|}{ Dependent variables } \\
\hline & \multicolumn{2}{|c|}{ 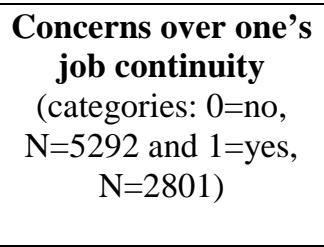 } & \multicolumn{2}{|c|}{ 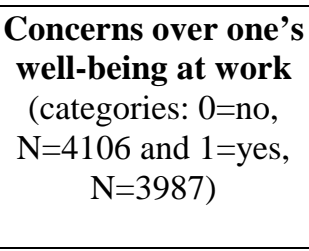 } & \multicolumn{2}{|c|}{ 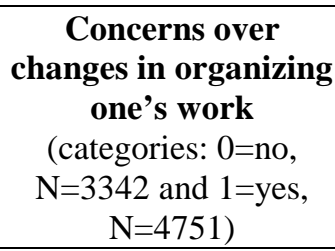 } \\
\hline & Sig. & $\begin{array}{l}\text { Odds } \\
\text { ratio }\end{array}$ & Sig. & $\begin{array}{l}\text { Odds } \\
\text { ratio }\end{array}$ & Sig. & $\begin{array}{l}\text { Odds } \\
\text { ratio }\end{array}$ \\
\hline $\begin{array}{l}\text { Gender } \\
\text { (female N=1844, reference category: male } \\
\mathrm{N}=6249 \text { ) }\end{array}$ & .166 & .728 & .708 & .919 & .399 & .823 \\
\hline $\begin{array}{l}\text { Age (reference category: over the age of } \\
50 \text { years } N=1527 \text { ) }\end{array}$ & .000 & & .000 & & .000 & \\
\hline 30 years or under $(\mathrm{N}=1487)$ & .000 & 2.088 & .000 & .511 & .091 & .764 \\
\hline $31-40$ years $(\mathrm{N}=2225)$ & .000 & 1.941 & .610 & 1.080 & .182 & 1.227 \\
\hline $41-50$ years $(\mathrm{N}=2854)$ & .020 & 1.481 & .763 & .957 & .070 & 1.311 \\
\hline $\begin{array}{l}\text { Personnel group (reference category: } \\
\text { Other soldier } N=3181 \text { ) }\end{array}$ & .000 & & .042 & & 101 & \\
\hline Civilian expert $(\mathrm{N}=1250)$ & .000 & 2.042 & 123 & .760 & .604 & 1.099 \\
\hline Civilian worker (N=1841) & .000 & 2.814 & .030 & 685 & 195 & .795 \\
\hline Officer ( $\mathrm{N}=1821)$ & .138 & 642 & .009 & .541 & 171 & .734 \\
\hline $\begin{array}{l}\text { Interactions } \\
\text { Gender and age } \\
\text { Gender and personnel group } \\
\text { Age and personnel group }\end{array}$ & $\begin{array}{l}.008 \\
.020 \\
.009\end{array}$ & & $\begin{array}{l}.072 \\
.005 \\
.000\end{array}$ & & $\begin{array}{l}.919 \\
.883 \\
.045\end{array}$ & \\
\hline
\end{tabular}




\begin{tabular}{|l|ll|ll|ll|}
\hline $\begin{array}{l}\text { Opportunities to develop oneself and } \\
\text { one's skills at work (weak N=1137, } \\
\text { reference category: good or rather good } \\
\text { N=6956) }\end{array}$ & $\mathbf{. 0 1 2}$ & 1.205 & $\mathbf{. 0 0 0}$ & 1.432 & $\mathbf{. 0 0 2}$ & 1.293 \\
\hline $\begin{array}{l}\text { Opportunities to advance one's career } \\
\text { (hardly any N=4209, reference category: } \\
\text { good or rather good N=3884) }\end{array}$ & $\mathbf{. 0 0 3}$ & 1.189 & $\mathbf{. 0 0 0}$ & 1.323 & $\mathbf{. 0 0 0}$ & 1.283 \\
\hline $\begin{array}{l}\text { Social climate and team spirit } \\
\text { (continuous sum variable with three items } \\
\text { (scale 1-5, } \alpha=0.818, \text { mean 4.06, standard } \\
\text { deviation 0.84) N=8093 }\end{array}$ & .905 & 1.005 & $\mathbf{. 0 0 0}$ & .779 & .881 & .994 \\
\hline $\begin{array}{l}\text { Leadership and management } \\
\text { (continuous sum variable with five items } \\
\text { (scale 1-5, } \alpha=0.865, \text { mean 3.76, standard } \\
\text { deviation 0.91) N=8093 }\end{array}$ & $\mathbf{. 0 0 0}$ & .756 & $\mathbf{. 0 0 0}$ & .670 & $\mathbf{. 0 0 0}$ & .519 \\
\hline Constant & .080 & & $\mathbf{. 0 0 0}$ & & $\mathbf{. 0 0 0}$ & \\
\hline
\end{tabular}

Of the other independent variables, opportunities to develop oneself at work and opportunities to advance one's career were significant when explaining all three dependent variables. Those who had good opportunities in both of these variables had fewer concerns in each dependent variable. Social climate was significant only in explaining 'concerns over one's well-being at work', but leadership and management was significant in explaining all three dependent variables. Those who reported that the leadership and management was good at their workplace had fewer concerns than those who did not consider them as good. The variance analysis shows that gender and personnel group had significant main effects on both sum variables. Social climate and leadership and management were assessed to be better by male respondents than by female respondents. Officers (including female and male respondents) assessed both these variables better than other personnel groups. No significant interaction effects were found.

Investigating two-way interaction effects in logistic regression is more complicated than studying the main effects because there are two reference categories in group comparisons. The significant interactions between categories depend on which groups are chosen as reference categories. On the other hand, a significant interaction term for all respondents is not dependent on reference categories. In Table 1, only the interaction effects between gender, age, and personnel group for all respondents are presented, and group comparisons in cases of significant interaction effects have been done in a descriptive way by examining graphical plots of interactions (Figure 1, interactions A to F). On the vertical axes is the predicted probability for each category, which is actually the same as the mean (in scale $0-1$ ) for each category. A high probability indicates that more concern was shown in this category relative to the categories with lower probabilities. In the final logistic regressions, there were six statistically significant interactions. The same interaction terms were also significant in the second stage of analysis.

All the two-way interactions were significant in explaining 'concerns over one's job continuity'. First, the interaction between gender and age showed that men in different age groups had fewer concerns relative to women, and there was not much variation between the age categories (Figure 1, interaction A). The curve of the female respondents of different age categories has more variation, especially in the category of those over the age of 50 years, and the curve is closer to that of the male respondents of the same age. A second significant interaction was found between gender and personnel group (Figure 1, interaction B). The curves of both women and men indicate the same kind of variation in different personnel groups. Civilian workers had more concerns and officers clearly fewer concerns relative to other groups. It is interesting that the curves cross each other, so the female civilian experts and other soldiers had more concerns than men in these personnel 
groups. On the other hand, female civilian workers and officers had fewer concerns relative to men in both personnel groups. A third significant interaction was the one between age and personnel group (Figure 1, interaction C). The curves of the three youngest age categories seem to mirror each other, and they have a similar kind of variation among the personnel groups. From these age categories, civilian workers had more concerns and officers fewer concerns relative to others, as in the case of the interaction between gender and personnel group. In this case, it is interesting that those over the age of 50 years had fewer concerns relative to the other age categories in each personnel group. The difference compared with the other age categories was the greatest in civilian workers.

There were two significant interactions explaining the dependent variable 'concerns over one's well-being at work' (Figure 1, interaction D). First, in each personnel group, women had more concerns relative to men, and the difference was greatest in civilian experts and lowest in officers. However, male officers seemed to have slightly more concerns than male respondents in other personnel groups, and female civilian experts quite clearly had more concerns relative to female respondents in other personnel groups. The second significant interaction was between age and personnel group (Figure 1, interaction E). Officers over the age of 50 years had fewer concerns than younger officers. Actually, officers and other soldiers aged 31-40 and 41-50 seemed to have quite a lot of concerns, and the youngest age category seemed to have on average fewer concerns relative to other the age categories, except relative to officers.

Finally, in explaining the dependent variable 'concerns over changes in organizing one's work', there was one significant interaction between age and personnel group (Figure 1, interaction F). Officers had fewer concerns than other personnel groups, especially officers over the age of 50 years. The youngest respondents had on average fewer concerns than the older age categories, and civilians had more concerns than officers and other soldiers 


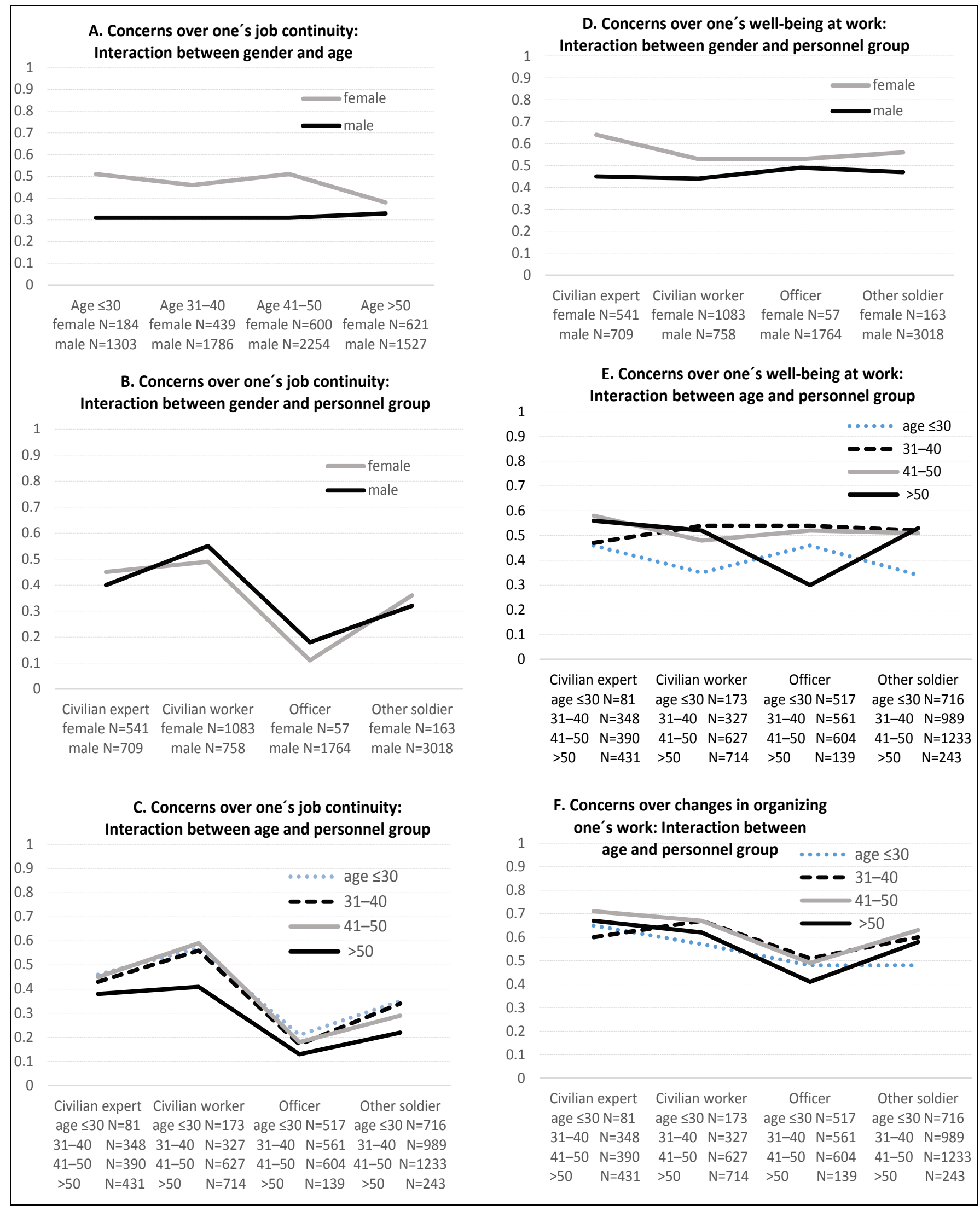

Figure 1. Concerns over one's job continuity, well-being at work and changes in organizing one's work. The statistically significant interactions are between gender, age and personnel group $(\mathrm{p} \leq$ 0.05). 


\section{Discussion}

In line with McCall's (2005) intercategorical approach, our analysis shows that the plain examination of main effects of the variables is insufficient; the interaction effects of the variables must also be examined. As the dependent variables were binary, logistic regression was selected for statistical analyses. This method is especially suitable for studying the complexity of relationships of variables in a specific context (Hurrell 2014; Olsen \& Morgan 2005). In order to find out the complex relationships of effect, the statistical analysis was carried out in three consecutive stages.

In the first stage, we found that all independent variables (gender, age, personnel group, defence branch, and nature of work) had significant main effects on at least three of the five dependent variables (concerns). However, in the second stage, some of the significant main effects disappeared (especially in the case of gender). Instead, we found several statistically significant interactions between gender, age, and personnel group. In the third stage, we added the context-related independent variables to the analysis. These were 'opportunities to develop oneself' and 'one's skills at work', 'opportunities to advance one's career', and two sum variables: social climate and leadership and management. In the third stage, significant interactions between variables remained. In addition to that, both poor 'opportunities to develop oneself' and one's skills at work and poor 'opportunities to advance one's career' increased 'concerns over job continuity', 'well-being at work', and 'changes in organizing one's work'. Furthermore, those who reported being more satisfied with leadership and management experienced fewer concerns in terms of these issues, whereas those who reported to be more satisfied with social climate experienced fewer concerns over their well-being at work.

Earlier research on the FDF and international research on military organizations (Heiskanen et al. 2015; Leinonen et al. 2008; Leinonen et al. 2012; Persson 2011; Tallberg 2009) indicates that military organizations are formed by hierarchical and vertical divisions. In this article, we have explored how these divisions are established in a changing organization. Since the changes at the time of data collection had meant the reorganization of training below officer rank, and a reduction of civilian positions and an on-going process of reorganizing the services they provide, it was a reasonable assumption that these changes would affect the concerns experienced by the different employee groups.

The career structure of the FDF was reflected in the findings. Not only is the system organized to build and support officer careers, in practice it means that most management and leadership positions were preserved for those in military positions (especially officers). Therefore, we explored the organizational context more closely through the lenses of social climate and experiences of management and leadership. (Allen et. al 2007, 205-207; Piderit 2000, 792; Tierney 1999, 129131)

The findings bring to light the civil/military hierarchy within the organization. The primacy of positions that are in or near the military core is reflected in how (un)certain the employees see their future in the organization and how positively they evaluate their opportunities for self-development and career advancement. Those working in support tasks (primarily civilians) had the most concerns over their job continuity. The career system of military personnel is supported by training systems of the organization that relate to different stages of the military career. 
The civil/military hierarchy and gender hierarchy are interconnected, and the priority of this mechanism varies. For example, while in general women had more concerns over their job continuity, by looking more closely at the relationship between gender and position, the differences between women in different positions could be discovered. Female officers consider their position quite secure, as do male officers. In civilian expert positions, men were slightly less concerned about their job continuity than women, which might hint that a mechanism producing gender differences is at work. These women are also more concerned about their well-being at work. These findings indicate some sort of disparity between gender and position. To get a clearer picture of these features, a more intensive approach to the details and circumstances of women and men in different positions is required.

The civil/military hierarchy is a powerful differentiating mechanism for both women and men: concerns over job continuity also vary among men depending on their position. The reorganization of worker tasks has also affected men's perspectives and experiences concerning the vulnerability of their position in the organization. Age is relevant both within and outside specific personnel groups, and it is attached to the military career structure. In general, the youngest employees had the least concerns over the organizational changes. This can be linked to the stage of their career in officer positions and the physical experience of age. For example, while the oldest officer group had the fewest concerns over their well-being, the youngest age group were the second-least concerned. One can assume that their relative youth compensates for the demands of their tasks. To obtain a deeper understanding, a more intensive look into the details of the career structure and the training cycles needed to further one's career is required. Age seems to work in favour of the oldest officers (who are all men), whereas concerns over well-being and organizational changes particularly affect the senior civilian employees in expert positions.

The disappearance of the main effects of gender in the second stage of the analysis and the statistical interactions found between gender, age, and personnel group not only highlight the importance of the analytical approach McCall urges researchers to explore, but shows that the gender mechanism usually works hand-in-hand with other mechanisms, which is often making it difficult to grasp. In the FDF, gender, age and occupational group can be seen as significant socio-structural categories that produce unequal allocations of benefits and resources. These discoveries emphasize that in efforts to diminish the gender hierarchy, all the organizational processes must be addressed simultaneously. This seems to be especially true in the case of strongly hierarchical organizations like the military. When different categories are included in the analysis, the variation in the employees' experiences increases. Although employees share the organizational context, the organization is not the same for everyone.

\section{Limitations and challenges}

We have presented some of the obvious reasons for the differences between the groups. At this stage, however, our explanations must be considered tentative. Through the concept of inequality regimes, Acker (2006a; 2006b) shows that there are a variety of practices and processes in the daily life of the organizations that may result and maintain - intentionally or unintentionally inequalities between social groups. Analogically, it is possible that in the military organization there are structures, practices, and processes that in the context of change treat people in various positions and groups differently, and this may lead to concerns and ambiguities in the personnel's experiences. Like Elizabeth Cole (2009), we assert that the type of quantitative method applied here can be a valuable tool for revealing patterns of disparity. Nevertheless, we also share her reservations that it may not be sensitive enough to detect nuanced differences across groups. In 
addition, we want to point out that our interpretations are based on the results of a statistical model with specified variables. The combination of some other variables might yield different results. Due to the multiplicity of potential reasons for the consequences for the specified groups, research might benefit from the combination of different research strategies or multi-level approaches, as, for example, Winker and Degele suggest (2011).

\section{Conclusions}

We have aimed to contribute to intersectional analysis in organizations using quantitative methods. Differing from McCall's macro-level analysis, our study focuses on organizational-level phenomena, making the lived experiences of the organization members more accessible. This research has made visible how experiences vary, and how, at least tentatively, these experiences are the products of certain mechanisms. We have highlighted some of the structures, practices, and processes that might be behind the mechanisms. We discovered that the same context of change in the organization creates disadvantages for some groups and leaves other groups untouched (cf. McCall 2005, 1790). It is important for diversity and change management to be aware of such divergent consequences and the degree to which diversity exists empirically (cf. Spierings 2012).

Intersectional intercategorical analysis focuses on the relations between categories. The methodological limitations of the study relate to the size of the dataset. Although our dataset was large, it was not possible to conduct a three-way analysis because of the size of some groups. This type of analysis does not provide the tools for a nuanced investigation into the mechanisms behind differentiating experiences. To further enhance the interpretation of the results, further contextual knowledge is needed. Thus, designs with mixed methods (e.g. Hurrell 2014) might provide a valuable contribution in understanding the complexities behind the experiences, as might some sort of multi-level approach (e.g. Winker and Degele 2011).

\section{References}

Acker, J. (2012), “Gendered organizations and intersectionality: problems and possibilities”, Equality, Diversity and Inclusion: An International Journal, Vol. 31 No. 3, pp. 214-224.

Acker, J. (2006a), “Inequality regimes”, Gender, class and race in organizations, Gender \& Society, Vol. 20 No. 4, pp. 441-464.

Acker, J. (2006b), “Class Questions, Feminist Answers”, New York, Rowman \& Littlefield Publishers, Inc.

Allen, J.; Jimmieson, N.; Bordia, P. and Irmer, B.E. (2007), "Uncertainty during Organizational Change: Managing Perceptions through Communication”, Journal of Change Management, Vol. 7 No. 2, pp. 187-210.

Britton, D. and Logan, L. (2008), “Gendered Organizations: Progress and Prospects”, Sociology Compass Vol. 2 No.1, pp. 107-21.

Cho, S. and Crenshaw, K. W. and McCall, L. (2013), “Toward a Field of Intersectionality Studies: Theory, Applications, and Praxis”, Signs: Journal of Women in Culture and Society Vol. 38 No. 4, pp.785-810.

Choo, H. E. and Ferree, M. M. (2010), "Practicing Intersectionality in Sociological Research: A 
Critical Analysis of Inclusions, Interactions, and Institutions in the Study of Inequalities”, Sociological Theory Vol. 28 No. 2, pp. 129-149.

Cole, E. R. (2009), “Intersectionality and Research in Psychology”, American Psychologist, Vol. 64, No. 3, pp. 170-180.

Crenshaw, K. (1991), “Mapping the Margins: Intersectionality, Identity Politics, and Violence Against Women of Color”, Stanford Law Review Vol. 43, pp. 1241-1279.

Davis, K. (2008), “Intersectionality as buzzword: A sociology of science perspective on what makes a feminist theory successful”, Feminist Theory, Vol. 9 No. 1, pp. 67-85.

de los Reyes, P. and Mulinary, D. (2005), ”Intersektionalitet - Kritiska reflektioner över (o)jämlikhetens landskap”, Malmö, Liber.

Hair, J. F. \& Black, W. C. \& Babin, B.J. \& Andersson, R. E. (2010), “Multivariate Data Analysis”, 7th edition, Prentice Hall, New Jersey.

Healy, G. (2009), “Reflections on researching inequalities and intersectionality”, in Özbilgin, M.F. (ed.) Equality, Diversity and Inclusion at Work. A Research Companion, Edward Elgar Publishing Limited, Cheltenham, pp. 88-100.

Heiskanen, T.; Otonkorpi-Lehtoranta, K.; Leinonen, M. and Ylöstalo, H. (2015), "Gender issues on change agenda - Practising intersectionality in action research”, Gender, Work, and Organization, forthcoming.

Holvino, E. (2010), "Intersections: The Simultaneity of Race, Gender and Class in Organization Studies”, Gender, Work and Organization, Vol. 17. No. 3, pp. 248-277.

Hurrell, S.S. (2014), "Critical realism and mixed methods research: Combining the extensive and intensive at multiple levels”, in Edwards, P.K.; O’Mahoney, J. and Vincent, S. (eds.) Studying Organizations Using Critical Realism, Oxford University Press, Oxford, pp. 241-263.

Leinonen, M.; Nikkanen, R. and Otonkorpi-Lehtoranta, K. (2012), "Sukupuolten tasa-arvo puolustusvoimissa - Kehittämistarpeiden näkökulma asepalvelusta suorittavien ja henkilöstön kokemuksiin" [Gender Equality in the Finnish Defence Forces], Work Research Centre, Working Papers 88/2012, University of Tampere, Tampere.

Leinonen, M.; Talola, N.; Terävä, S. and Uosukainen, K. (2008), "Naisten ja miesten työhyvinvointi ja tasa-arvo puolustusvoimissa 2007" [Gender Equality and Well-Being at Work in the Finnish Defence Forces in 2007], Maanpuolustuksen tieteellinen neuvottelukunta, sarja A 2008/3, Helsinki.

Lykke, N. (2010), “Feminist Studies. A guide to Intersectional Theory, Methodology and Writing”. Routledge, New York \& London.

Lykke, N. (2005), ”Nya perspektiv på intersektionalitet”, Kvinnovetenskaplig tidskrift, Vol. 2-3, pp. 7-17.

McCall, L. (2005), “The Complexity of Intersectionality”, Signs, Journal of Women in Culture 
and Society, Vol. 30 No. 3, pp. 1771-1800.

Mulinari, P. and Selberg, R. (2013), "Intersectional Directions in Working Life Research - a Proposal”, Nordic journal of working life studies, Vol. 3 No. 3, pp. 81-98.

Olsen, W. \& Morgan, J. (2005) "A Critical Epistemology of Analytical Statistics: Addressing the Sceptical Realist”, Journal for the Theory of Social Behaviour, Vol. 35 No. 3, pp. 255-284.

Persson, A. (2011), "Changing Boundaries, Defending Boundaries. Gender Relations in the Swedish Armed Forces”, Linköping Studies in Arts and Science No. 546, Linköping University, Linköping.

Piderit, S.K. (2000), "Rethinking Resistance and Recognizing Ambivalence: A Multidimensional View of Attitudes toward an Organizational Change”, The Academy of Management Review, Vol. 25 No. 4, pp. 783-794.

Smith M.J. (1998), “Social Science in Question”, Sage

Publications in association with The Open University, London, Thousand Oaks \& New Delhi.

Spierings, N. (2012), "The inclusion of quantitative techniques and diversity in the mainstream of feminist research”, European Journal of Women's Studies Vol. 19 No. 3, pp. 331-347.

Tabachnick, B.G. \& Fidell, L.S. (2013), “Using Multivariate Statistics. 6th edition”, USA, Pearson.

Tallberg, T. (2010),’Kuviot uusiksi? Maanpuolustuksen organisointi ja turvallisuuden valtavirtaistaminen" [The organizing of national defence and mainstreaming of security], in Jukarainen, P. and Terävä, S. (eds) Tasa-arvoinen turvallisuus? Sukupuolten yhdenvertaisuus suomalaisessa maanpuolustuksessa ja kriisinhallinnassa, Minerva Kustannus Oy, Helsinki, pp. 2735.

Tallberg, T. (2009), “The Gendered Social Organisation of Defence: Two Ethnographic Case Studies in the Finnish Defence Forces”, Economics and Society 193, Hanken School of Economics, Helsinki.

Tatli, A. and Özbilgin, M.F. (2012), “An Emic Approach to Intersectional Study of Diversity at Work: A Bourdieuan Framing”, International Journal of Management Reviews, Vol. 14 No. 2, pp. 180-200.

Thorvaldsdottir, T. (2007), "Equal Opportunities for All” - Intersectionality as a Theoretical Tool to Move Equality Policies Forward, http://www8.umu.se/kvf/aktuellt/ppf/tthorvaldsdottir.pdf. Last accessed 27th January 2015.

Tierney, P. (1999), "Work relations as a precursor to a psychological climate for change", Journal of Organizational Change Management, Vol. 12 No. 2, pp. 120-134.

Verloo, M. (2013), "Intersectional and Cross-Movement Politics and Policies: Reflections on Current Practices and Debates”, Signs, Journal of Women in Culture and Society, Vol. 38 No. 4, pp. 893-915. 
Verloo, M. (2006), “Multiple inequalities, intersectionality and the European Union”, European Journal of Women's Studies, Vol. 13 No. 3, pp. 211-228.

Winker, G. and Degele, N. (2011), "Intersectionality as multi-level analysis: Dealing with social inequality”, European Journal of Women’s Studies, Vol. 18 No. 1, pp. 51-66.

Yuval-Davis, N. (2006), “Intersectionality and feminist politics”, European Journal of Women's Studies, Vol. 13 No. 3, pp. 193-209. 